\title{
E-learning readiness and its correlates among secondary school teachers in Nablus, Palestine
}

\author{
F.A.A. Trayek, T.B. Tunku Ahmad \& M.S. Nordin \\ Institute of Education, International Islamic University Malaysia, Kuala Lumpur, Malaysia
}

\begin{abstract}
This study explored the readiness levels of the secondary school teachers in Nablus to adopt e-learning in four important aspects: technological, psychological, equipment, and overall e-learning readiness, and the influence of gender on these aspects. A total of 475 teachers (236 males and 239 females) from 24 secondary schools in Nablus participated in the survey that employed a 23-item questionnaire measuring the readiness constructs on a 5-point Likert scale. The items were first content validated by experts and pilot-tested before being administered to the respondents. The data were analyzed quantitatively using descriptive statistics, independent-samples $t$-tests, Cohen's $d$ for effect sizes, and Pearson's product-moment correlation tests. The results showed that secondary school teachers in Nablus were quite psychologically ready to use e-learning, but this aspect was not equally supported by technological and equipment readiness. Technological, equipment and psychological readiness were all found to be significant correlates of e-learning readiness with quite strong influences. Statistically significant gender differences were detected for technological, equipment and overall e-learning readiness, but not for psychological readiness. However, the magnitude of the differences was considered small based on the interpretation of Cohen's $d$ for effect sizes. The findings have important implications on what the Palestinian Ministry of Education and Nablus school principals need to put in place in order to better prepare their teachers and schools for e-learning.
\end{abstract}

\section{INTRODUCTION}

\subsection{Background of the study}

In Palestine today, students and teachers' mobility is severely restricted by checkpoints, roadblocks, and gated passages which are manned by heavily-armed Israeli soldiers and sometimes guarded with tanks. Due to these travel restrictions between and within Palestinian cities, journeys of short distances often stretch into hours and have adversely affected the education of Palestinian citizens. It has been reported that, "just as their parents have trouble getting to their workplaces, children and young adults are frequently denied their right to education. They are forced to take dangerous routes to their schools and universities. Hundreds of students have been detained, shot or injured on their way to school. In addition, Israeli forces sometimes order schools to be temporarily closed - occasionally these closures have lasted for a year or longer" (If Americans Knew Website, 2013, p. 2). The report clearly indicates how Israeli occupation has denied the Palestinian people their right and access to education.

\subsection{The concept of e-learning and its benefits}

E-learning may be a viable solution to the conflict in Palestine that is affecting its education. The term was coined by Cross (2004) to refer to learning enabled by the Internet, a networked environment, and other multiple electronic formats, such as CD-ROMs and DVD-ROMs. It has also been defined as a system that uses multimedia technologies for content delivery, user interaction, or learning facilitation (Ngai, Poon, \& Chan, 2007). Its purpose is to improve the quality of learning by facilitating access to resources and services on a learning management system, such as Moodle and Blackboard, as well as facilitating exchanges and distance collaboration. In Israeli-occupied Palestine where students and teachers often never made it to school, e-learning may be the only means of extending access to education to Palestinian students.

E-learning can be synchronous, asynchronous, instructor-led or computer-based. As such, it is useful in the Palestinian context as it extends learning beyond the boundaries of time, space and location, and reduces the amount of travelling to attend school. Moreover, educational institutions that use e-learning solutions save money on printing expenses (Rosenberg, 2000), which is indeed useful for Palestinians who are now living in extreme poverty and suffering from one of the worst recessions in modern history (The World Bank Report, 2012).

\subsection{Problem statement}

Israeli occupation has made the progress of Palestinian education nearly impossible (Nicolai, 2007). The difficult situations brought about by Israeli aggression have led to marked increases in teacher absence 
and students' dropout rates (Al-Haq Report, 2005). Nablus is one of the Palestinian cities deeply affected. Under the immensely restricting conditions, e-learning comes across as a good option to advance and sustain the education of the Palestinian people, and should be implemented in Palestinian schools as an educational strategy, particularly in Nablus. However, the readiness or ability of Nablus schools and teachers to adopt and implement e-learning is not known due to a lack of empirical research in this aspect.

\section{RESEARCH OBJECTIVES}

This study was conducted with three main objectives: (i) to assess the readiness levels of secondary school teachers in Nablus to adopt e-learning in three important dimensions, i.e. psychological, technological and equipment readiness; (ii) to determine whether there were gender differences in the three dimensions of e-learning readiness, and (iii) to establish whether technological readiness, psychological readiness and equipment readiness were significant correlates of e-learning readiness among teachers in Nablus.

\section{LITERATURE REVIEW}

Chapnick (2000) proposed a model with eight factors to measure the e-learning readiness of an organization, i.e. psychological readiness (the user's state of mind and mental attitude towards e-learning); sociological readiness (the interpersonal aspects of the environment in which e-learning will be implemented); environmental readiness (the large-scale forces operating on the stakeholders both inside and outside the organization); human resource readiness (the availability and design of the human-support system); financial readiness (the budget size and allocation process); technological readiness (observable and measurable technical competencies); equipment readiness (the proper equipment possession); and content readiness (the subject matter and goals of the instruction to be delivered via e-learning). She suggested that for each context and stakeholder group, a different combination of factors is examined.

The importance of Chapnick's factors in influencing e-learning readiness, whether in full or in part, has been reiterated by other researchers. In their study, Raturi, Hogan, and Thaman (2011) found access and experience with technology to play a major role in preparing students for e-learning. Pirani (2004) maintained that institutions must provide adequate and reliable technical infrastructure to support e-learning activities (equipment readiness), instructors and students must possess the technical skills to use e-learning tools (technological readiness) and instructors must redesign their courses to incorporate e-learning effectively into their pedagogy (content readiness). Technological skills and ability have consistently been shown to affect readiness for and acceptance of e-learning among different user groups, i.e. teachers (Hadjiathanasiou, 2009); students (Akaslan \& Law, 2011; Ali, 2010); lecturers (Agboola, 2006; Al-Senaidi, Lin, \& Poirot, 2009); and human resource managers (Aydin \& Tasci, 2005); as well as in different settings, i.e. universities (Saekow \& Samson, 2011), schools (Mulwa \& Kyalo, 2013), the agricultural sector (Ahmadpour, Mirdamadi, Hosseini, \& Chizari, 2010), and the private sector (Nleya, 2009). Bukaliya and Mubika (2011) and Sadik (2007) showed that teachers had a low level of readiness to use e-learning as they did not have the necessary ICT knowledge and skills, ICT training, software and hardware knowledge, on top of available infrastructure. All these studies pointed to how multiple technological competencies played a significant role in determining the readiness to adopt e-learning. In this regard, Akaslan and Law (2011) emphasized the paramount importance of relevant ICT training for enhancing e-learning readiness and the likelihood of e-learning uptake.

Butler and Sellborn (2002) listed technology reliability (part of equipment readiness) as the most important technology acceptance factor, followed by knowledge of how to use the relevant technology (technological readiness) and beliefs that the technology benefits learning (psychological readiness). Mulwa and Kyalo (2013) recently established no significant influences or relationships between positive psychological predisposition towards e-learning and the general readiness to embrace the technology, while Chow, $\mathrm{Ng}$ and Che Mat (2007) reported a significant positive association between students' e-learning readiness and ICT literacy, but a non-significant relationship with positive mental attitudes. While previous research has demonstrated the importance of one type of readiness over the other, and some possibility of relationships among the e-readiness constructs, the results however are not clear-cut and conclusive. There is little information that indicates whether psychological, technological and equipment readiness are indeed significant correlates of e-learning readiness.

Similarly, findings on gender influences on these constructs have been varied. Several studies found no significant gender differences in their respondents' general e-learning readiness (Teo, Wong, Thammetar, \& Chattiwat, 2011; Purnomoi \& Lee, 2010; Soydal, Alır, \& Ünal, 2011). Females have been reported to show higher levels of mental preparedness (Alenezi, 2012) and technological readiness (Raturi et al., 2011) for e-learning, but no statistically significant gender differences were observed. Likewise, Jaafar, Ramayah, Abdul-Aziz, and Saad (2007) discovered the same non-gender effect on Malaysian managers' technological readiness, although they did demonstrate high levels of it. These disagreed with the findings of So and Swatman (2006) which showed male and female in-service teachers in Hong Kong to differ significantly in technological readiness. However, the same gender effect was not observed among pre-service teachers, suggesting that technological preparedness tends to decrease among younger 
samples. The inconclusiveness of these results merits further research in e-learning readiness in the context of Palestinian teachers and schools.

\section{METHOD}

\subsection{Data collection and instrument}

Nablus has a total of 24 secondary schools; 12 for boys and 12 for girls. Data were collected invidually with the help of school principals from all the 24 schools using a 23 -item questionnaire that measured e-learning in three aspects: psychological readiness ( 7 items), technological readiness ( 9 items), and equipment readiness ( 7 items). The items were adapted from Chapnick (2000) and previous studies on e-learning, and measured the constructs on a 5-point Likert scale ranging from Strongly Agree (5) to Strongly Disagree (1). The internal consistency indexes of the constructs measured using Cronbach's alpha were .89 for psychological readiness, .84 for technological readiness, and .83 for equipment readiness.

\subsection{Population and sample}

As of August 2012, the total population of teachers serving in the 24 Nablus schools numbered at 554 , out of which $51 \%(\mathrm{n}=282)$ were female and $49 \%(\mathrm{n}=272)$ were male. The questionnaire was administered to all 554 teachers and 475 responded, constituting a response rate of $85.7 \%$. The sample was comprised of $49.7 \%$ male and $50.3 \%$ female, with $75 \%$ aged between 24 and 45 . Close to $79 \%$ held a bachelor's degree, while $14.5 \%$ and $6.5 \%$ had a master's degree and a diploma respectively. Most of the respondents reported having at least one computer lab at their schools $(95 \%)$, while $5 \%$ did not have any. However, $67 \%$ reported no Internet connection at their respective schools. This was a factor that greatly affected the equipment readiness of these schools.

\subsection{Data analysis}

The data were analysed using four statistical procedures. To address research objective one, descriptive statistics (frequency counts and percentages) and bar charts were utilized to present the results descriptively and visually. The visual presentation enabled main trends and patterns to be captured clearly. To address research objective two, respondents' responses were summated to obtain a total score each for technological, psychological, equipment, and e-learning readiness. The summated scores were then subjected to a series of independent-samples $t$-test analyses to establish gender differences, if any. Cohen's $d$ for effect sizes was used to determine the practical importance of the mean differences between male and female teachers. To address research objective 3, Pearson's Product Moment correlation procedures were run on all four scores representing technological, psychological, equipment, and e-learning readiness to

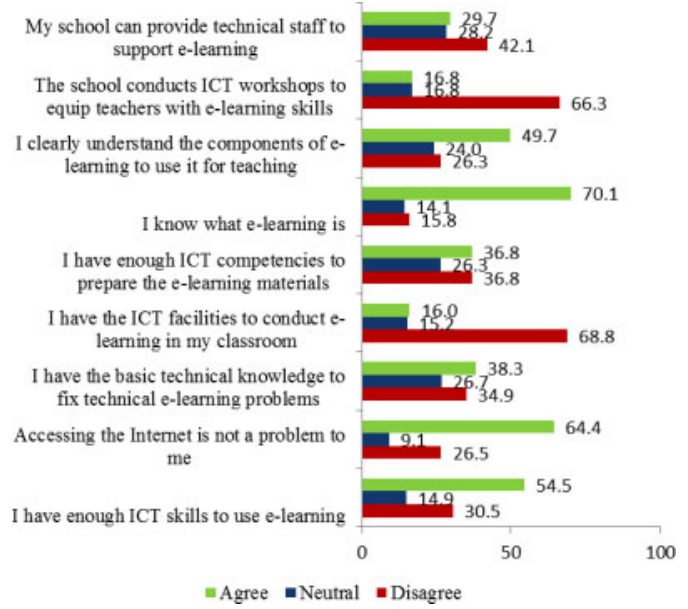

Figure 1. Respondents' Agreement to Technological Readiness Items (\%).

determine the relationships among the constructs and the strength of their associations.

\section{RESULTS}

\subsection{Technological readiness}

The respondents' agreement to the nine technological readiness items is shown in Figure 1.

A majority indicated knowing what e-learning is (70.1\%), knowing how to access the Internet (64.4\%), and having enough ICT skills to use e-learning (54.5\%). Still a majority but a lesser percentage of agreement was observed for the understanding of e-learning components $(49.7 \%)$. These four items showed a clear majority agreeing. Items with a clear majority disagreeing were: (i) having the ICT facilities to implement e-learning in the classroom $(68.8 \%$ disagreeing), (ii) the school conducting ICT workshops to equip teachers with e-learning skills $(66.3 \%)$, and (iii) the school providing the technical staff to support e-learning $(42.1 \%)$. The remaining two items (having the skills to fix e-learning problems and prepare e-learning materials) saw a divided response among the respondents. This means that the respondents who said they could fix e-learning problems $(38.3 \%)$ and prepare e-learning materials $(36.8 \%)$ were as many as those who said they could not $34.9 \%$ and $36.8 \%$ respectively). The pattern of responses indicates that most respondents were confident about their own skills and knowledge in e-learning, but doubted if their respective schools would be able to support its implementation with adequate facilities, technical staff and skills building workshops.

\subsection{Psychological readiness}

Figure 2 shows the respondents' agreement to the seven psychological readiness items. 


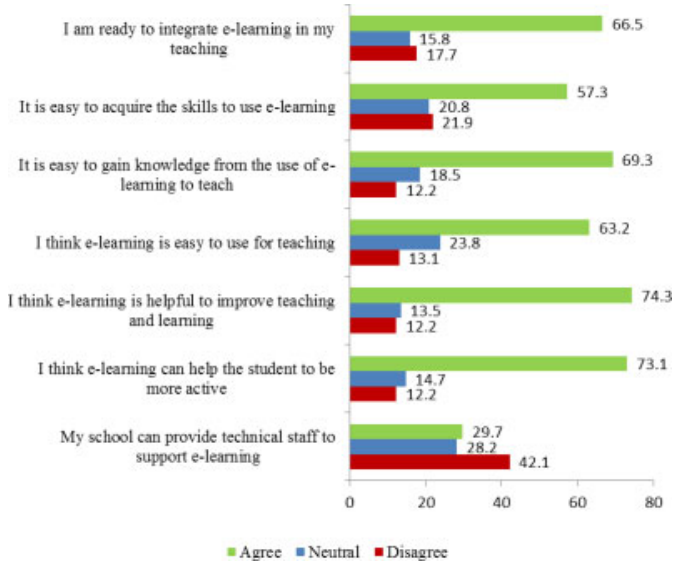

Figure 2. Respondents' Agreement to Psychological Readiness Items (\%).

All items received an overwhelmingly positive response from the respondents, recording a percentage of agreement from $57.3 \%$ (on e-learning skills are easy to acquire) to $74.3 \%$ (on e-learning improves teaching and learning). An exception was the provision of technical staff by the school to facilitate e-learning implementation, which was supported by only $29.7 \%$. More than $42 \%$ disagreed that their respective schools provided the support needed. The pattern of responses shows that most respondents were psychologically ready for e-learning implementation in Nablus. They generally had a positive psychological predisposition towards e-learning, believing that they had the necessary requirements to make it happen and that it was a useful solution to advance teaching and learning in the city. However, most doubted that their schools would be able to provide e-learning technical support.

\subsection{Equipment readiness}

Figure 3 shows respondents' agreement to the seven equipment readiness items. Only two items received a majority of positive response from the respondents, i.e. schools having projectors $(64.6 \%)$ and printers $(62.3 \%)$ that work well. This indicates that most schools in Nablus did have these two facilities to support computing activities, but not necessarily e-learning, as e-learning would not require much printing. However, less than half of the respondents did not agree that their schools possessed good CD-ROM drives, which is an important facility for e-learning if the Internet is not functioning. A revealing finding is the number of respondents reporting a lack of Internet connection at their respective schools $(62.9 \%)$, which is a critical factor influencing the success of an e-learning initiative. Close to half of the respondents also disagreed that their schools had enough computer labs $(47.4 \%)$ and up-to-date facilities $(47.2 \%)$ to support e-learning, and that their schools' IT infrastructure could implement the technology $(45.9 \%)$. In general, as shown by the results, most of the respondents

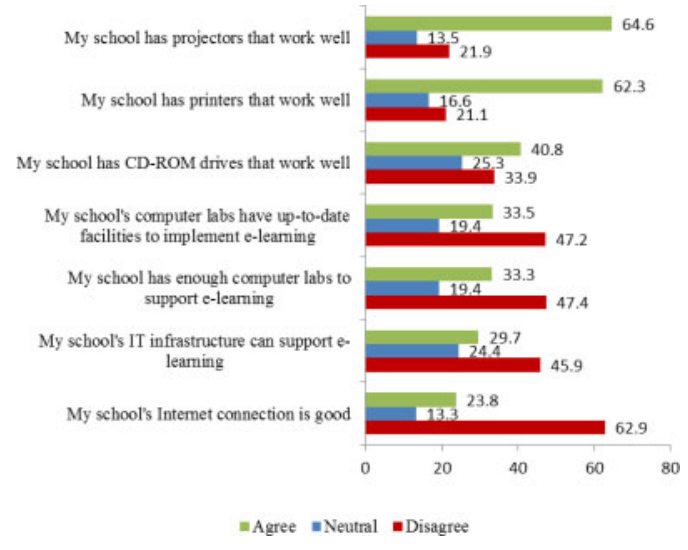

Figure 3. Respondents' Agreement to Equipment Readiness Items (\%).

Table 1. $t$-Test Results on Gender Differences in Respondents' Technological, Psychological, Equipment and E-Learning Readiness $(\mathrm{N}=475 ; \mathrm{df}=473)$.

\begin{tabular}{llllll}
\hline $\begin{array}{l}\text { Readiness } \\
\text { Construct }\end{array}$ & $\mathrm{M}$ & $\mathrm{SD}$ & $t$ & $p$-value & $\begin{array}{l}\text { Cohen's } \\
d\end{array}$ \\
\hline TR & & & & & \\
- Male & 27.76 & 4.73 & 2.190 & $.029^{*}$ & 0.20 \\
- Female & 26.81 & 4.69 & & & \\
$\begin{array}{l}\text { PR } \\
\text { - Male }\end{array}$ & 24.96 & 3.89 & 0.889 & $.375^{* *}$ & 0.08 \\
- Female & 24.65 & 3.69 & & & \\
$\begin{array}{l}\text { ER } \\
\text { - Male }\end{array}$ & 21.58 & 4.08 & 2.628 & $.009^{*}$ & 0.24 \\
- Female & 20.59 & 4.14 & & & \\
$\begin{array}{l}\text { ELR } \\
\text { - Male }\end{array}$ & 74.29 & 10.8 & 2.516 & $.012^{*}$ & 0.23 \\
- Female & 72.05 & 9.27 & & & \\
\hline
\end{tabular}

Notes: $\quad \mathrm{TR}=$ technological readiness; $\mathrm{ER}=$ equipment readiness; $\mathrm{PR}=$ psychological readiness; $\mathrm{ELR}=\mathrm{e}$-learning readiness.

had negative opinions about their respective schools' equipment readiness by which a good system of e-learning can be implemented.

\subsection{Gender differences in the readiness constructs}

As shown by the results in Table 1, male teachers superseded females in all the constructs of e-learning readiness. Statistically significant gender differences were found for three of these constructs, namely technological readiness $[t(473)=2.190, p=0.029]$, equipment readiness $[t(473)=2.628, p=0.009]$, and e-learning readiness $[t(473)=2.516, p=0.012]$, all in favour of the male respondents. This means that male teachers in Nablus secondary schools reported significantly higher levels of readiness in terms of the skills, infrastructure, and equipment needed for a workable e-learning implementation. However in terms of practical importance, the effect sizes for the mean differences are considered small at Cohen's $d$ of 0.20 (technological readiness), 0.24 (equipment readiness) 
Table 2. Summary of Correlation Analysis Results $(\mathrm{N}=475)$.

\begin{tabular}{llll}
\hline $\begin{array}{l}\text { Relationship } \\
\text { Between Constructs }\end{array}$ & $\begin{array}{l}\text { Pearson's } \\
r\end{array}$ & $\begin{array}{l}p \\
\text { value }\end{array}$ & $\begin{array}{l}\text { Strength of } \\
\text { Association }\end{array}$ \\
\hline TR and ELR & .839 & $.001^{*}$ & strong \\
ER and ELR & .704 & $.001^{*}$ & strong \\
PR and ELR & .767 & $.001^{*}$ & strong \\
TR and PR & .534 & $.001^{*}$ & moderate \\
TR and ER & .351 & $.001^{*}$ & weak \\
ER and PR & .288 & $.001^{*}$ & weak \\
\hline
\end{tabular}

Notes: $\quad \mathrm{TR}=$ technological readiness; $\mathrm{ER}=$ equipment readiness; $\mathrm{PR}=$ psychological readiness; $\mathrm{ELR}=\mathrm{e}$-learning readiness; *statistically significant at $p<0.05$.

and 0.23 (e-learning readiness), which were values just slightly above the threshold of 0.20 for small effect sizes (Cohen, 1988). With respect to psychological readiness, no statistically significant gender differences were found, although male teachers did show a higher mean score on the readiness scale.

\subsection{Relationships among the readiness constructs}

Pearson's correlation procedures run on the summated scores of all four readiness constructs showed statistically significant positive relationships among them (Table 2).

The respondents' e-learning readiness was significantly and positively correlated with their technological readiness $(r=.839, p=.001)$, psychological readiness $(r=.767, p=.001)$, and equipment readiness $(r=.704, p=.001)$. The strength of associations among them was also high, exceeding the coefficient of 0.5 for strong correlations between variables. Statistically significant positive relationships also existed between technological readiness and equipment readiness $(r=.351, p=.001)$, although the strength of association is considered weak; between technological readiness and psychological readiness $(r=.534$, $p=.001)$; as well as between equipment readiness and psychological readiness $(r=.288, p=.001)$, which is also a weak correlation. The results show that technological, psychological, and equipment readiness were linearly correlated with one another, and significantly affected the overall e-learning readiness.

\section{DISCUSSION AND CONCLUSION}

The patterns of responses reveal that most teachers may possess the psychological readiness for e-learning, but it was not wholly supported by their technological ability and their respective schools' equipment readiness. Most Nablus teachers did not believe that their respective schools had the necessary equipment, technology and ability to deliver e-learning to students in the Palestinian city. The lack of belief was echoed in the responses towards many items in the questionnaire. Hence in summary, although the teachers saw the huge potential and benefits of e-learning for students in Nablus, and may fully welcome the idea (psychological readiness), they may not be fully technologically ready for e-learning in terms of their own ICT ability (technological readiness) and schools' capacity to provide the necessary support and infrastructure (equipment readiness).

Although a majority claimed to have the basic e-learning skills and theoretical understanding, most lacked the ability to prepare e-learning materials and fix technical problems associated with it. As e-learning depends largely on computers and the Internet, these two competencies are very crucial in ensuring the success of any e-learning effort. Thus, there is an urgent need for schools and relevant authorites in Nablus to provide the necessary training to equip teachers with critical e-learning skills, and the technical staff to support its implementation, as well as improve the existing e-learning infrastructure and ICT facilities. The two most urgent infrastructure needed to be put in place are reliable Internet connection and up-to-date computer labs.

Technological, psychological and equipment readiness were found to be significant correlates of e-learning readiness with strong associations, consistent with the findings of Bukaliya and Mubika (2011). The strongest correlate was technological readiness $(r=.839)$, followed by psychological readiness $(r=$ $.767)$, and equipment readiness $(r=.704)$. This suggests that an increase in any of these factors would lead to an increase in Nablus teachers' general e-learning readiness. The discovery of technological preparedness as a strong correlate of e-learning readiness agrees with the findings of Hadjiathanasiou (2009), Chow et al. (2007), Akaslan and Law (2011), Ali (2010), Agboola (2006), Al-Senaidi et al. (2009), Aydin and Tasci (2005), Saekow and Samson (2011), Mulwa and Kyalo (2013), Ahmadpour et al. (2010), and Nleya (2009).

Gender was discovered to have a relatively small influence on all of these correlates, with effect sizes ranging between Cohen's $d=0.20$ and $d=0.23$. Even though male teachers and boys' schools in Nablus may appear to be more fully equipped in terms of ICT facilities, e-learning skills, and infrastructure, the gender disparity among these factors was slight and negligible. The results did not disagree with what was established by Teo et al. (2011), Purnomoi and Lee (2010), and Soydal et al. (2011), suggesting that gender differences where ICT and e-learning are concerned may be disappearing.

\section{REFERENCES}

Akaslan, D., \& Law, E.L.C. 2011. Measuring Teachers' Readiness for E-learning in Higher Education Institutions associated with the Subject of Electricity. Proceedings of 2011 IEEE Global Engineering Education Conference: Learning Environments and Ecosystems in Engineering Education, EDUCON-2011, Amman, Jordan.

Akaslan, D., \& Law, E.L.C. 2011. Measuring student e-learning readiness: a case about the subject of electricity 
in higher education institutions in turkey. Advances in Web-Based Learning-ICWL 2011: Lecture Notes in Computer Science 7048: 209-218.

Alenezi, A. 2012. Faculty Members' Perception of E-learning in Higher Education in the Kingdom of Saudi Arabia (KSA). Unpublished Doctoral Dissertation. Texas Tech University. Retrieved from http://repositories.tdl.org/ttuir/handle/2346/45399.

Ali, I.E.H. 2010. Measuring students e-readiness for e-learning at egyptian faculties of tourism and hotels. Paper presented at the 6th International Scientific Conference on E-Learning and Software for Education, Bucharest, April 15-16, 2010.

Agboola, A.K. 2006. Assessing the awareness and perceptions of academic staff in using elearning tools for instructional delivery in a post-secondary institution: a case study. The Public Sector Innovation Journal 11(3): $2-12$.

Ahmadpour, A., Mirdamadi, M., Hosseini, J.F., \& Chizari, M. 2010. Factors affecting the development of electronic learning in agricultural extension network in iran. MiddleEast Journal of Scientific Research 5(4): 261-267.

Al-Haq Report. 2005, April 12. Palestinian education under israeli occupation. Paper Presented at the Conference on International Law in the Shadow of Israeli Occupation, Stockholm, Sweden.

Al-Senaidi, S., Lin, L., \& Poirot, J. 2009. Barriers to adopting technology for teaching and learning in Oman. Computers \& Education 53(3): 575-590.

Aydin, C. H., \& Tasci, D. 2005. Measuring readiness for e-learning: reflections from an emerging country. Educational Technology \& Society 8(4): 244-257.

Boffey, R., Gerrans, P., \& Kennedy, S. 2006. Using digital lectures to assist student learning. Paper presented at the 14th International Symposium on Improving Student Learning, University of Bath, UK, 4-6 September.

Bukaliya, R., \& Mubika, A. K. 2011. Teacher competence in ict: implications for computer education in Zimbabwean secondary schools. International Journal of Social Sciences \& Education 1(4): 414-425.

Butler, D. L., \& Sellborn, M. 2002. Barriers to adopting technology for teaching and learning. Educause Quarterly 9(4): 105-127.

Chapnick, S. 2000. Are you ready for e-learning? Learning Circuits: ASTD's Online Magazine All About Elearning. Retrieved from http://blog.uny.ac.id/nurhadi/files/2010/ 08/are_you_ready_for_elearning.pdf

Chow, S.H., Ng, S.F., \& Che Mat, S. 2007. An investigation on e-learning readiness of engineering students. The Institution of Engineers Malaysia Journal 68(4): 56-64.

Cross, J. 2004. An informal history of elearning. On the Horizon 12(3): 103-110.

Jaafar, M., Ramayah, T., Abdul-Aziz, A., \& Saad, B. (2007). Technology readiness among managers of Malaysian construction firms. Engineering, Construction and Architectural Management 14(2): 180-191.

Hsbollah, H. M., \& Idris, K. M. 2009. E-learning adoption: the role of relative advantages, trialability and academic specialisation. Campus-Wide Information Systems 26(1): 54-70.

Hadjiathanasiou, P. 2009. The e-learning readiness of cyprus primary teachers ahead of dias system integration into cyprus schools. The European Journal of Open, Distance and E-Learning, 1. Retrieved from http://www.eu rodl.org/index.php? article $=363$
If Americans Knew Website. 2013. Israeli checkpoints and their impact on daily life. Retrieved from http:// www.ifamericansknew. org/cur_sit/checkpoints.html

Mulwa, A.S., \& Kyalo, D.N. 2013. The influence of principals', teachers' and students' attitude on readiness to adopt e-learning in secondary schools in kitui district, kenya. European Scientific Journal 9(5): 183-202. Retrieved from http://eujournal.org/index.php/esj/article/ view/798/834

Ngai, E.W.T., Poon, J.K.L., \& Chan, Y.H.C. 2007. Empirical examination of the adoption of webct using TAM. Computers \& Education 48(2): 250-267.

Nicolai, S. 2007. Fragmented foundations: Education and chronic crisis in the occupied Palestinian territory. Paris, France: UNESCO, IIEP, and London, England: Save the Children UK

Nleya, P.T. 2009. Relative levels of e-learning readiness, applications and trainee requirements in Botswana's Private Sector. Canadian Journal of Learning and Technology 35(1). Retrieved from http://cjlt.csj.ualberta. ca/index.php/cjlt/article/view/511/241

Pirani, J. 2004. Supporting e-learning in higher education. Educause Center for Applied Research. Retrieved from http://net.educause. edu/ir/library/pdf/ers0303/ecm0303. pdf

Purnomoi, S. H., \& Lee, Y. H. 2010. An assessment of readiness and barriers towards ict programme implementation: perceptions of agricultural extension officers in indonesia. International Journal of Education and Development using Information and Communication Technology (IJEDICT) 6(3): 19-36.

Raturi, S., Hogan, R. \& Thaman, K. H. 2011. Learners' access to tools and experience with technology at the University of the South Pacific: Readiness for e-learning. Australasian Journal of Educational Technology 27(3): 411-427. Retrieved from http://www.ascilite. org.au/ajet/ajet27/raturi.html

Rosenberg, M.J. 2000. E-learning: strategies for delivering knowledge in the Digital Age. Ohio: McGraw-Hill.

Sadik, A. 2007. The readiness of faculty members to develop and implement e-learning: the case of an egyptian university. International Journal on E-Learning 6(3): 433-453.

Saekow, A., \& Samson, D. 2011. E-learning readiness of Thailand's universities comparing to the USA's cases. International Journal of e-Education, e-Business, e-Management and e-Learning 1(2): 126-131.

So, T., \& Swatman, P.M.C. 2006. E-learning readiness of Hong Kong teachers. Hong Kong IT in Education Conference 2006 "Capacity Building for Learning through IT" (HKITEC2006), February 6-8, 2006, Hong Kong Exhibition and Convention Centre, Hong Kong.

Soydal, I., Alır, G., \& Ünal, Y. 2011. Are turkish universities ready for e-learning: a case of Hacettepe University Faculty of Letters. Information Services \& Use 31: 281-291.

Teo, T., Wong, S.L., Thammetar, T., \& Chattiwat, W. 2011. Assessing the e-learning acceptance of university students in Thailand. Australasian Journal of Educational Technology 27(8): 1356-1368. Retrieved from http://www.ascilite.org.au/ajet/ajet27/teo.html

The World Bank Report. 2012, March 21. Stagnation or Revival? Palestinian Economic Prospects Economic Monitoring Report to the Ad Hoc Liaison Committee. Retrieved from http://siteresources.worldbank. org/INTWESTBANKGAZA/Resources/WorldBankAHL CreportMarch2012.pdf 